\title{
Information System Prediction With Weighted Moving Average (WMA) Method And Optimization Distribution Using Vehicles Routing Problem (VRP) Model for Batik Product
}

\author{
Tri Agustina Nugrahani ${ }^{1, *}$, Kusworo $\mathrm{Adi}^{2}$, and Jatmiko Endro Suseno ${ }^{2}$ \\ ${ }^{1}$ Magister of Information System, School of Postgraduate Studies, Diponegoro University, Semarang - Indonesia \\ ${ }^{2}$ Department of Physics, Faculty of Sains and Mathematic, Diponegoro University, Semarang - Indonesia
}

\begin{abstract}
Distributing the products evenly to the customers is the problem faced by the producer of batik product. The purpose of this research is to optimize product distribution using demand prediction data from each store. The way of distributing products affects products brand and revenue in society. To cover this problem we propose the method to fulfil customers demand and to promote the brand by using Weighted Moving Average (WMA) to forecast product demand in each distributor store. To deliver the product for the customer, we are using the model of Vehicle Routing Problem (VRP) and Sequential Insertion Algorithm. We obtained the result that both distribution cost and travel time of distribution is successfully reduced. The results obtained that the WMA method can predict product demand by generate the small error value with MAPE the result is 0 until $17 \%$ which classified as very accurate-good. For distribution optimization using the VRP model and Sequential Insertion algorithms the result of optimal costs is IDR 36244, with a previous cost is IDR 150.000 in one month so can reduce $75 \%$. Besides that, the travel time is 130.05 minutes with the distance $69.7 \mathrm{~km}$, and routes that have been optimized.
\end{abstract}

Keywords: batik product; distribution; optimization; weighted moving average (WMA); vehicle routing problem (VRP); algorithm sequential insertion.

\section{Introduction}

This research in demand forecasting error is utilizing The Weighted Moving Average Method (WMA). In each data periods, it has the weight which is using to support the WMA. After that, for the result of the prediction, it is examined the error value. This method computes the averages of the data with the bigger given weight from the venerable data. [1]. The method of the WMA is showing the fact that the oldest data has more influence to help in finding the right value's error hence it is given the biggest weight value among the other data. [2]. The Mean Absolute Percent Error (MAPE on this research is implemented to test the error of the data prediction.

As the definition, The WMA is a prediction method which placing different weights to the available historical data or the recent data. [3]. In order to know the market demand, in the early stage, there is a prediction phase which is establishing and creating to understand the market demand. In this research is different on weighted value of WMA. The other research used weighted 1 on the calculation, the selected is 0.05 ,
0.15 , and 0.80 [4]. However in this research same use weighted 1 but for 3 periods, is $0.01,0.09$, and 0.9 . This weighted obtained from experiment, do prediction calculations, and search for values close to the actual values. The improvement for this research of the former research is the real-time situation problem. [5]. The target of this research is completing previous research which its problem was about not yet real-time. The data is input in VRP model when its data is gained and the error already checked. There is a condition that must be met to process the distribution of the products. VRP model has been massively utilized for instance in food distributions which is based on the consumer and distributor locations, hence the customers' demand are able to fulfill and trimming the emissions of the utilized vehicles. [6]. In this research VRP is used to optimize the distribution and its completed by inserting sequential insertion algorithmthe sequential insertion technique working with the specific criteria or the lowest cost then accomplish the route perfectly is the algorithm called sequential insertion algorithm [7]. Sequential insertion algorithm employment to optimize the distribution product based on the lowest travel funds.

* Corresponding author: nugrahanina22@gmail.com 


\section{Theory}

\subsection{Weighted Moving Average (WMA)}

The demand prediction of the products has to be calculated. hence, it will result in a proper data to fit into the condition of the VRP. The data used for WMA is the element sale's data from 2016. it data sale is divided into monthly periods. Here the mathematical formulation of WMA, describe in follows. [4].

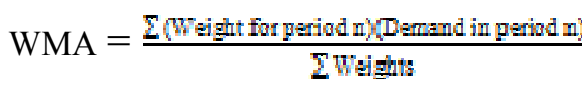

WMA is considered very important because it is able to provide real-time information about the demand of the products. In this research is different on weighted value of WMA. The other research used weighted 1 on the calculation, for 3 months selected is $0.05,0.15$, and 0.80 [4]. However, in this research same use weighted 1 but for 3 periods, weighted on this research is $0.01,0.09$, and 0.9. This weighted obtained from experiment, do prediction calculations, and search the smallest values of MAPE.

After the prediction result is obtained, then it continues calculating the error testing of the WMA result. To calculated accuracy value of WMA error, then Mean Absolute Percent Error (MAPE) is begin to be used. Calculation of the error accuracy on WMA [1], can be calculated using the formula $\mathrm{A}=$ sales data actual, $\mathrm{F}=$ prediction data product, $\mathrm{n}=$ number of period and $\mathrm{t}=$ denotes value in period.

$$
\mathrm{MAPE}=\sum_{i=1}^{\mathrm{n}} \frac{100\left|A_{\mathrm{T}}-F_{\mathrm{i}}\right| \mathrm{A}_{4}}{\mathrm{I}}
$$

MAPE have the limitation in rules, that are shown in Table 1. Accuracy Prediction of MAPE [8].

Table 1. Accuracy Prediction of MAPE

\begin{tabular}{|c|c|}
\hline MAPE & Accuracy \\
\hline Less than $10 \%$ & Highly accurate \\
\hline $10-20 \%$ & Good \\
\hline $20-50 \%$ & Reasonable \\
\hline Greater than $50 \%$ & Inaccurate \\
\hline
\end{tabular}

\subsection{Vehicle Routing Problem (VRP)}

VRP is a problem related to the logistics optimization, this problem contributes and opportunities to reduce logistics costs especially on vehicle routing [9]. In the method of the VRP, the vehicle will transport the product from producer to several stores, then the vehicle will return bcak to producer. The purpose of this VRP is to minimize distance and minimization of the vehicle is used and still meet the demand of either locations or stores. Notation and the mathematical formulas that used ini this study is [10]:

\section{Parameters}

P producer node

D delivery node for store

0 node for producer

$\mathrm{n}$ number of node

b moment the service start at the store

$\mathrm{V}$ number of vehicle

$\mathrm{m}$ indeks of vehicle from $\mathrm{i}$ to $\mathrm{V}$

$\mathrm{Q}_{\mathrm{m}} \quad$ maximum capacity of vehicle $\mathrm{m}$

$\mathrm{p}_{\mathrm{i}} \quad$ quantity to picked up in node $\mathrm{i}$ (produser)

$\mathrm{d}_{\mathrm{i}} \quad$ quantity to deliver in node $\mathrm{i}$ (store)

$\mathrm{tc}_{\mathrm{ij}}$ transportation cost from node $\mathrm{i}$ to $\mathrm{j}$

$\mathrm{c}_{\mathrm{m}} \quad$ operational cost of vehicle $\mathrm{m}$

\section{Decision Variables}

$\mathrm{x}_{\mathrm{ijm}} 1$, if vehicle $\mathrm{m}$ moved from $\mathrm{i}$ to $\mathrm{j}$

0 , otherwise

$\mathrm{Z}_{\mathrm{ij}} \quad$ amount to transported from node $\mathrm{i}$ to node $\mathrm{j}$ in delivery process

To resolve the distribution to be more optimal then given mathematical model for optimization of the distribution of batik products [10].

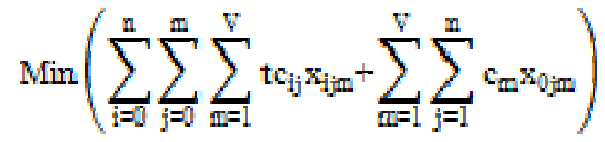

From model of calculation 3 is to finding minimal transportation cost of the vehicle. In this case the operational cost of vehicle not calculated, because its unpredictable and there is no information from producer. There are 9 mathematical formulas in VRP boundary requirements [10]:

1. There is only 1 vehicle coming through from one node (store)

$$
\sum_{\mathrm{i}=0}^{\mathrm{n}} \sum_{\mathrm{m}=1}^{\mathrm{v}} \mathrm{x}_{\mathrm{ijm}}=1 \forall \mathrm{i}
$$

2. There is only 1 vehicle that goes past from one node (store) back to producer

$$
\sum_{i=0}^{n} \sum_{m=1}^{v} x_{i j m}=1 \quad \forall j
$$

3. There are all tracks mus be visited by vehicle

$$
\sum_{i=0}^{n} x_{i b m}=\sum_{j=0}^{n} x_{b j m} \forall b, m
$$


4. Departing vehicle has left the producer

$$
\sum_{\mathrm{i}=1}^{\mathrm{n}} \mathrm{x}_{\mathrm{i} 0 \mathrm{~m}} \leq 1 \forall \mathrm{m}
$$

5. Declare that return of vehicle had stopped at producer

$$
\sum_{j=1}^{n} x_{0 j m} \leq 1 \quad \forall m
$$

6. To ensure that all vehicles departing from producer are less than the total vehicle or vehicle must be sufficient

$$
\sum_{m=1}^{V} \sum_{j=1}^{I} x_{0 i m} \leq V \forall m
$$

7. That guarantee the number of delivery of products does not exceed the capacity of the vehicle in the process delivered product

$$
\mathrm{z}_{\mathrm{ij}} \leq \mathrm{Q}_{\mathrm{m}} \cdot \mathrm{x}_{\mathrm{ijm}} \forall \mathrm{m}, \forall \mathrm{i}, \mathrm{j}
$$

8. Declare of all the product taken from producer must be deliver to store

$$
\sum_{i=1}^{n} p_{i}=\sum_{i=1}^{n} d_{i}
$$

9. The number of products transported between node is calculated for the delivering process

$$
\mathrm{z}_{\mathrm{ij}}-\mathrm{z}_{\mathrm{ib}}=\left\{\begin{array}{ll}
\mathrm{d}_{\mathrm{j}}, & \text { if } \mathrm{j} \in \mathrm{D}, \forall \mathrm{vi}, \mathrm{b} \\
0, & \text { if } \mathrm{j} \in \mathrm{P}, \forall \mathrm{i}, \mathrm{b} \\
-\sum_{\mathrm{i}=1}^{\mathrm{n}} \mathrm{d}_{\mathrm{l},}, & \text { if } \mathrm{j} \in 0, \forall \mathrm{i}, \mathrm{b}
\end{array}\right\}
$$

\section{Method}

To solve the problem by making the customer slip into the consumer, the method of sequential algorithm is used [11]. Find the initial solution that refers to the first customer selection process entering into route.

Flowchart of the Sequential Insertion Algorithm is able to be seen in Figure 1. Sequential insertion algorithm has 5 steps for insertion that are described as follows [5]:

Step $1^{\text {st }}$. Insert the data, by input the real-time data of the products' demand.

Step $2^{\text {nd }}$. Identifiy scope of the problem, by sorting out the stores having request for Batik products.

Step $3^{\text {rd }}$ Determine the first store those visited can be used alternatively choosing the fasthest or the nearest store [12]. After the first store is selected, find the node that having the smallest or the lowest cost of all nodes.

Step $4^{\text {th }}$. Selected data is entered then updates the connected data. Updating the data to the system by inserting the node has the smallest cost into the product delivery route design.

Step $5^{\text {th }}$. Terminate the checking process of the data. When all of the nodes are already met the condition then insert the vehicles on any initial route. After that it can be concluded that the stage is completed. However, if there are vehicles cannot fulfill the capacity, it can be down into small pieces of delivery and then it is re-inserted by route or go back to step 3 .

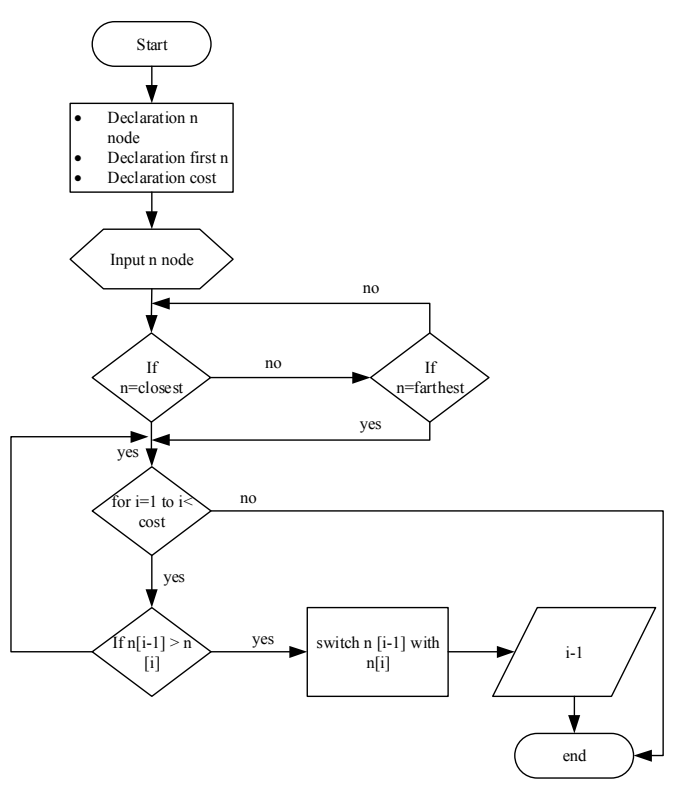

Fig. 1. Flowchart of sequential insertion algorithm

\section{Result And Discussion}

In this study the case, we are using the data gained from UD. Batik Rolla Jember. Determination of study case because UD. Batik Rolla have big rotation of product. Result of this research can also be used other producer or companies have the same problem. Predicted demand for batik product is continued with optimizing the distribution using VRP method and the sequential insertion algorithm. WMA is used to calculates the sale activity data batik 001 in 2016. Table 2. Sales Data is data used.

Table 2. Sales Data

\begin{tabular}{|c|c|c|c|}
\hline Periods & Month & Sales & Year \\
\hline 1 & January & 35 & \\
\cline { 1 - 3 } 2 & February & 33 & \\
\cline { 1 - 3 } 2 & March & 33 & \\
& \multirow{2}{*}{2016} \\
\hline 4 & April & 34 & \\
\cline { 1 - 3 } & Mei & 33 & \\
\cline { 1 - 2 } 6 & Juni & 33 & \\
\hline 7 & July & 30 & \\
\hline
\end{tabular}

This research use weight 1 for 3 periods, weighted on this research is $0.01,0.09$, and 0.9 . This weighted 
obtained from experiment, do prediction calculations, and search for smallest MAPE values. The experiment from weighted $=1$ on Table 3 . Experiment Of Weighted.

Table 3. Experiment of Weight

\begin{tabular}{|c|c|c|c|c|c|c|c|c|}
\hline \multirow{2}{*}{ no } & \multirow{2}{*}{$\begin{array}{c}\text { Name } \\
\text { of } \\
\text { batik }\end{array}$} & \multicolumn{3}{|c|}{ weight } & \multirow{2}{*}{$\mathrm{F}$} & \multirow{2}{*}{ A } & \multirow{2}{*}{ mape } & \multirow{2}{*}{ weight } \\
\hline & & n 1 & $\mathrm{n} 2$ & n 3 & & & & \\
\hline 1 & $\begin{array}{c}\text { batik } \\
1\end{array}$ & 35 & 35 & 33 & 33 & 33 & 0 & \multirow{3}{*}{$\begin{array}{c}0.05 \\
0.15 \\
0.80\end{array}$} \\
\hline 2 & $\begin{array}{c}\text { batik } \\
2\end{array}$ & 35 & 33 & 23 & 25 & 23 & 3 & \\
\hline 3 & $\begin{array}{c}\text { batik } \\
3\end{array}$ & 33 & 33 & 32 & 32 & 30 & 2 & \\
\hline 1 & $\begin{array}{c}\text { batik } \\
1\end{array}$ & 35 & 35 & 33 & 34 & 33 & 1 & \multirow{3}{*}{$\begin{array}{c}0.1 \\
0.3 \\
0.6\end{array}$} \\
\hline 2 & $\begin{array}{c}\text { batik } \\
2 \\
\end{array}$ & 35 & 33 & 23 & 27 & 23 & 6 & \\
\hline 3 & $\begin{array}{c}\text { batik } \\
3\end{array}$ & 33 & 33 & 32 & 32 & 30 & 3 & \\
\hline 1 & $\begin{array}{c}\text { batik } \\
1\end{array}$ & 35 & 35 & 33 & 34 & 33 & 1 & \multirow{3}{*}{$\begin{array}{c}0.05 \\
0.2, \\
0.75\end{array}$} \\
\hline 2 & $\begin{array}{c}\text { batik } \\
2\end{array}$ & 35 & 33 & 23 & 26 & 23 & 4 & \\
\hline 3 & $\begin{array}{c}\text { batik } \\
3 \\
\end{array}$ & 33 & 33 & 32 & 32 & 30 & 3 & \\
\hline 1 & $\begin{array}{c}\text { batik } \\
1\end{array}$ & 35 & 35 & 33 & 34 & 33 & 1 & \multirow{3}{*}{$\begin{array}{c}0.1 \\
0.2 \\
0.7\end{array}$} \\
\hline 2 & $\begin{array}{c}\text { batik } \\
2\end{array}$ & 35 & 33 & 23 & 26 & 23 & 5 & \\
\hline 3 & $\begin{array}{c}\text { batik } \\
3 \\
\end{array}$ & 33 & 33 & 32 & 32 & 30 & 3 & \\
\hline 1 & $\begin{array}{c}\text { batik } \\
1\end{array}$ & 35 & 35 & 33 & 33 & 33 & 0 & \multirow{3}{*}{$\begin{array}{c}0.03 \\
0.07 \\
0.9\end{array}$} \\
\hline 2 & $\begin{array}{c}\text { batik } \\
2 \\
\end{array}$ & 35 & 33 & 23 & 24 & 23 & 2 & \\
\hline 3 & $\begin{array}{c}\text { batik } \\
3\end{array}$ & 33 & 33 & 32 & 32 & 30 & 2 & \\
\hline 1 & $\begin{array}{c}\text { batik } \\
1\end{array}$ & 35 & 35 & 33 & 33 & 33 & 0 & \multirow{3}{*}{$\begin{array}{c}0.01 \\
0.09 \\
0.9\end{array}$} \\
\hline 2 & $\begin{array}{c}\text { batik } \\
2\end{array}$ & 35 & 33 & 23 & 24 & 23 & 1 & \\
\hline 3 & $\begin{array}{c}\text { batik } \\
3\end{array}$ & 33 & 33 & 32 & 32 & 30 & 2 & \\
\hline
\end{tabular}

After knowing the sales data and the, then its calculate by using WMA method, and the error values is computing utilizing the MAPE. WMA method is used the 3 last data periods. The weight of the 3 periods of the data must be equal to 1 . Weight for each period are 0.01 , 0.09 , and 0.9, according to Table 3 number 11 . Calculation results from WMA method is shown in Table 4.

Table 4. Calculation Results of WMA

\begin{tabular}{|c|c|c|c|c|}
\hline Period & Month & A & F & MAPE (\%) \\
\hline 1 & April & 34 & 33 & 0.96 \\
\hline 2 & Mei & 33 & 34 & 0.91 \\
\hline 3 & Juni & 33 & 33 & 0 \\
\hline 4 & July & 30 & 33 & 3.34 \\
\hline
\end{tabular}

In Table 4 is the calculated 4 periods with used data in Table 3. For the results of MAPE is less than $10 \%$ that shows in Table 1, then the result is less than $10 \%$ then it could say that the result is highly accurate.

In this study, producer have a vehicle with the capacity of 500 products per vehicle. The demand to achieve the optimization is the data request that calculated using WMA. As the data requested to optimization phase are store location, producer, and distance.

For the first step it is related to the VRP constraints. VRP model is used to underrate the total cost for distribution of the product. According to the VRP rules, to ensure the met of the product demand in every store, we are using the WMA method to the first time analysis, then to optimize the route using VRP model and sequential insertion algorithm. Data sales were previously used by manufacturers to predict and distribute their products. Before the method is used to calculate as it is now, that manufacturers depend on orders based on location to find the prediction value. it is effected the distribution jam which is caused by the long distance of travel..

There are several steps using to implement the sequential insertion algorithm, that are step 1 is prediction data of WMA used for demand of each store. Step 2 is identified demand and store required distribution product from each store on the Table 5.

Table 5. Location Store

\begin{tabular}{|c|c|c|c|c|}
\hline No & Name & Address & Latitude & Longitude \\
\hline $\mathbf{1}$ & A & Jl. Trunojoyo & -8.1755200 & 113.695546 \\
\hline $\mathbf{2}$ & B & Jl. Trunojoyo & -8.1754908 & 113.698968 \\
\hline $\mathbf{3}$ & C & Jl. Trunojoyo & -8.1753554 & 113.703741 \\
\hline $\mathbf{4}$ & D & $\begin{array}{c}\text { Jl. Gajah } \\
\text { Mada }\end{array}$ & -8.1731624 & 113.690762 \\
\hline $\mathbf{5}$ & E & $\begin{array}{c}\text { Jl. Gajah } \\
\text { Mada }\end{array}$ & -8.1820458 & 113.671956 \\
\hline $\mathbf{6}$ & F & Jl. Sumatra & -8.1684392 & 113.710952 \\
\hline $\mathbf{7}$ & G & $\begin{array}{c}\text { Jl. } \\
\text { Kalimantan }\end{array}$ & -8.1654868 & 113.712011 \\
\hline $\mathbf{8}$ & H & Bondowoso & -7.9708959 & 113.795475 \\
\hline $\mathbf{9}$ & J & Jl. Sriwijaya & -8.1843610 & 113.721586 \\
\hline $\mathbf{1 0}$ & L & $\begin{array}{c}\text { Jl. PB } \\
\text { Sudirman }\end{array}$ & -8.1671064 & 113.703957 \\
\hline
\end{tabular}

Table 6. the demand of each store, assumed in April. Product to be delivered to store with capacity maximum 500 product of batik. 
Table 6. Demand data from producer to each store

\begin{tabular}{|c|c|c|c|c|}
\hline No & Product & Month & $\begin{array}{c}\text { Number of } \\
\text { demand }\end{array}$ & Store \\
\hline 1 & Batik 001 & April & 33 & \multirow{5}{*}{ A } \\
\hline 2 & Batik 002 & April & 33 & \\
\hline 3 & Batik 003 & April & 32 & \\
\hline 4 & Batik 005 & April & 15 & \\
\hline 5 & Batik 011 & April & 33 & \\
\hline 6 & Batik 045 & April & 12 & $\mathrm{~F}$ \\
\hline 7 & Batik 001 & April & 11 & \multirow{2}{*}{ B } \\
\hline 8 & Batik 002 & April & 11 & \\
\hline 9 & Batik 007 & April & 13 & $\mathrm{C}$ \\
\hline 10 & Batik 008 & April & 10 & $\mathrm{D}$ \\
\hline 11 & Batik 003 & April & 14 & $\mathrm{E}$ \\
\hline 12 & Batik 002 & April & 11 & $\mathrm{G}$ \\
\hline 13 & Batik 004 & April & 18 & \multirow{2}{*}{$\mathrm{H}$} \\
\hline 14 & Batik 003 & April & 14 & \\
\hline 15 & Batik 008 & April & 12 & $\mathrm{~J}$ \\
\hline 16 & Batik 010 & April & 11 & $\mathrm{~L}$ \\
\hline
\end{tabular}

Step 3 and 4 is step for select the first node to deliver, for the next node is selected node that have smallest costs from all nodes. Total cost for deliver the product is assumed with vehicle travel capability is $15 \mathrm{~km}$ per liter, for price of pertalite fuel oil is IDR 7800. Total cost is a comparasion of the total distance $(\mathrm{km})$ and fuel usage. Following is the comparasion for determining the first node visited, there are 2 alternatives based on the nearest node and the farthest node. The initial route is assumed in Table 5. From the 10 store is finding the nearest route, and the first node is node L. Table 7 is the results of calculate total cost and route.

Table 7. Calculation of total cost from the nearest store

\begin{tabular}{|c|c|c|c|}
\hline No & Name & $\begin{array}{c}\text { Route } \\
\text { (km) }\end{array}$ & Cost (IDR) \\
\hline 1 & producer $-\mathrm{L}$ & 1.4 & 728 \\
\hline 2 & L-F & 1 & 520 \\
\hline 3 & F-G & 0.35 & 182 \\
\hline 4 & G-C & 3.7 & 1924 \\
\hline 5 & C-B & 0.26 & 135.2 \\
\hline 6 & B-A & 0.4 & 208 \\
\hline 7 & A-D & 0.65 & 338 \\
\hline 8 & D-E & 3.9 & 2028 \\
\hline 9 & E-J & 8.8 & 4576 \\
\hline 10 & $\mathrm{~J}-\mathrm{H}$ & 35.4 & 18408 \\
\hline 11 & H- producer & 26.7 & 13884 \\
\hline & Total & 82.56 & $42.931,2$ \\
\hline
\end{tabular}

The next selected route is the farthest route. The first farthest route is node $H$. The farthest route can be seen at Table 8.
Table 8. Calculation of total cost from the farthest store

\begin{tabular}{|c|c|c|c|}
\hline No & Name & Route (km) & Cost (IDR) \\
\hline 1 & producer-H & 26.3 & 13676 \\
\hline 2 & $\mathrm{H}-\mathrm{G}$ & 26.5 & 13780 \\
\hline 3 & G-F & 0.4 & 208 \\
\hline 4 & F-J & 3.5 & 1820 \\
\hline 5 & $\mathrm{~J}-\mathrm{C}$ & 2.5 & 1300 \\
\hline 6 & C-B & 0.5 & 260 \\
\hline 7 & B-A & 0.3 & 156 \\
\hline 8 & A-D & 0.7 & 364 \\
\hline 9 & D-E & 3.9 & 2028 \\
\hline 10 & E-L & 3.9 & 2028 \\
\hline 11 & L- producer & 1.2 & 624 \\
\hline \multicolumn{2}{|r|}{ Total } & 69.7 & 36244 \\
\hline
\end{tabular}

The results of optimation from the nearest route is IDR 42931 with total distance is $82.56 \mathrm{~km}$. The results of optimation from the farthest route is IDR 36244 with total distance is $69.7 \mathrm{~km}$. Then the results from 2 alternative is the farthest route and is optimal node.

The last is step 5 from sequential insertion algorithm. If the route still has a route that must be switch, and back to step 3. The results can reduce $75 \%$ from cost transportation from producer is IDR 150000 . For results the total time is assumed from Google Map the time is 130.5 minute.

\section{Conclusion}

WMA method can help producer to know demand of the product. Information results of WMA is accurate because already tested with MAPE. Accuracy of prediction is classified as highly accurate-good. The optimization distribution from model VRP and sequential insertion algorithm is good, because the research obtain the smallest cost from the farthest route. The results of farthest route is $69.7 \mathrm{~km}$ to total distance and IDR 36244 with the total time is 130.5 minute. Because of the producers commonly spent their time a lot, hence the gained result considerable very profitable. it is proven by the reducing the fuel cost for less than IDR 150.000 per month. The result successfully reduce $75 \%$ from spent money from producers. Therefore, this Therefore, it can be concluded that this research is useful for the industrial producers. The combinations between utilized algorithm and method yield a fine result in optimization and economic profit. From the optimization can reduce vehicle emissions, and the used of fuel oil. 


\section{References}

1. W. J. Stevenson and S. C. Chuong, Operations management an asian perspective (McGraw-Hill Education-Salemba Empat, Jakarta, 2015)

2. C. P. Tsokos, European Journal Of Pure And Applied Mathematics 3, 411 (2010)

3. V. A. Sobreiro, T. R. C. C. D. Costa, R. T. F. Nazario, J. L. E. Silva, E. A. Moreira, M. C. L. Filho, H. Kimura, and J. C. A. Zambrano, North American Journal of Economics and Finance 38, 89 (2016)

4. N. B. A. Bakar, S. Rosbi, International Academic Research Journal of Business and Technology, 31 (2016)

5. C. F. Hsueh, H. K. Chen, and H. W. Chou, In-Tech, $78(2008)$
6. T. Bosona, I. Nordmark, G. Gebresenbert, and D. Ljungberg, International Journal of Business and Management 8, 14 (2013)

7. S. Jarwaneh, S. Abdullah, Data Mining and Optimisation Research Group PLoS ONE, 10 (2015)

8. T. Baldigara, Sciedu Press 2, 88 (2013)

9. G. B. Alvarenga, G. R. Mateus, and G. de. Tomi, Computers and Operations Research, 1562 (2007)

10. S. Birim, International Strategic Management Conference, 149-158 (2016)

11. M. I. Hosny and C. L. Mumford, Journal of King Saud University-Computer and Information Sciences, 68 (2011)

12. A. Poot, G. Kant, and A. P. M. Wagelmans, Econometric Institute Report EI 9938/A, 1999 